\title{
Regulatory Framework for Poultry Slaughterhouses: Case Studies in Debotabek Area, Indonesia
}

\author{
A. Apriantini ${ }^{1)}$, A. K. Adhi ${ }^{2}$ \\ ${ }^{1)}$ Departemen Ilmu Produksi dan Teknologi Peternakan, Fakultas Peternakan, Institut Pertanian Bogor \\ 2) Departemen Agribisnis, Fakultas Ekonomi dan Managemen, Institut Pertanian Bogor \\ Jl. Agatis, Kampus IPB Dramaga, Bogor 16680 \\ Corresponding E-mail: astariapriantini.ipb@gmail.com
}

\begin{abstract}
The increase of the community consumption of animal source foods, especially chicken meat, is continuing to rise. In the process of animal slaughter in slaughterhouse, there are the high numbers of fraudulence, which affect to the food security issues. Therefore, the government made the regulation not only the central government regulations but also the local government regulations regarding poultry slaughterhouse license in order to the poultry slaughterhouse could be operated with the standard of hygiene, food safety, halal matter, animal welfare, and not pollute and disrupt the environment. In addition to the existing of the permit of local governments, it is expected to do monitoring and controlling easier to the slaughterhouse in their territory. But, there are still many chicken carcass those are distributed on the market which are derived from illegal (does not have formal permission) poultry slaughterhouse so that the hygiene and the halal matter are doubtful. The purpose of this study is to find the obstacles in regulations of the building of poultry slaughterhouse, which led many slaughterhouse, especially small and medium sized slaughterhouse, and trouble in getting license of the building of slaughterhouse legally. It is to be expected that this research can be the input for the government in making policy to ease the small and medium poultry slaughterhouse in legalizing their business. In addition, the research is expected to draw the situation and condition to the stakeholders of poultry slaughterhouse about the procedures and regulations in the region, especially debotabek, in building of the industry of poultry slaughterhouse.
\end{abstract}

Key words: poultry slaughterhouse, animal slaughterhouse regulation, spatial regulations, food safety

\section{INTRODUCTION}

Nationally, the regulations on animal husbandry and veterinary are arranged in act no. 41/2014 on amendments to the act no.18/2019 about animal husbandry and veterinary particularly on food security is regulated in article 58. Jakarta as the capital city of the Republic of Indonesia is considered as a national barometer regarding to various issues including issues related to food product security of poultry especially chicken meat. Approximately $75 \%$ of the chicken meat, which are consumed in Jakarta, are slaughtered manually at small scale (backyard facilities) located in sub-urban areas, such as Depok, Bogor, Tangerang, and Bekasi. The public health risks which are associated with these slaughter practices are enormous. The slaughtering of poultry should be relocated from residential areas to public or private slaughter facilities outside the residential areas to ensure the food safety, hygiene, and waste management. However, due to the high population growth, the settlement area in sub-urban area around Jakarta has rapid expansion. Therefore, slaughterhouse or agricultural area converted into residential areas.

The large number of slaughterhouses which stand side by side with residential areas resulted in the difficulty for them to have official permit to operate as poultry slaughterhouses because they can not fulfill the requirements of the city planning regulation on site permit therefore many poultry slaughterhouses are operating illegally without have any official permit. These unlicensed poultry slaughterhouses will cause less security control, cleanliness, and also the halal matter of the chicken meat. There are approximately $800 \mathrm{RPH}$ operating in Indonesia but only 25 slaughterhouses have an NKV (Veterinary Control Number). This phenomenon may indicate that the majority of slaughterhouses in Indonesia are in poor conditions and can not meet the requirements to have a legal permit (Rochadi et al, 2013). In west Java, there are many slaughterhouses which are not or less feasible due to some technical requirements and slaughtering procedures are not in accordance with the slaughtering regulation and SNI (Indonesia National Standard) (Rochadi \& Rivanda, 2014). Several regions make policy in the form of a Regional Regulation to minimize problems related to food security. Every city and district has an authority to arrange local regulations related to the building of poultry slaughterhouses. Regional regulations are technically still referring to national regulation, namely The Regulation of the Minister of Agriculture No.13/2010. The differences 
among the regional regulations because of the adaptation of the different conditions of the community and the local environment and also related to different city planning regulations.

The aim of this research is to investigate what the requirements and conditions are for the establishment and operations of private slaughterhouse operators in Debotabek and also to analyze the stumbling block occured during this process. As part of this investigation the official licensing requirements and registration procedures from district, provincial and national authorities are needed.

\section{METHODS}

\section{Approaches to Collect Information}

Data and related information are collected through in depth interview with the employee of Animal Husbandry of Regional Government in Depok, Bogor, South Tangerang, Kabupaten Tangerang, Kabupaten Bekasi (Debotabek) area. Data collection in stakeholder were done by in depth interview and filling the questionnaires. The data obtained were analyzed using descriptive analysis.

\section{General List of Sources of Information}

The information about Regulations, SOP's, and also technical and non-technical requirements which are related the regulations to build poultry slaughterhouses, including procedures, permits such as location permit, principal permit, and environment permit in national level were obtained by visiting Director of Veterinary Public Health of Agricultural Ministry of Indonesia in Greater Jakarta. Local regulations related to poultry slaughterhouse permit were obtained by interviewing head of livestock services in Debotabek (Depok, Bogor, Tangerang, and Bekasi) area. Furthermore, the information about time and cost in completing permit, the information about how they control and evaluate the stakeholders in obeying the regulations and technical regulations in buiding poultry slaughterhouses, and the information about "Land Planning" (Setting the layout of Animal Husbandry Special Area) were obtained from those local government agencies.

After obtaining information from the central and local government, confirmations in the field were also done by visiting medium and small scale poultry slaughterhouses in Debotabek Area, both private and local government poultry slaughterhouses. The goals of this activity are confirming the effectiveness of the applicaton of the regulations and permits, SOP's, and completion time in field (reality), confirming the obedience of the SOP's those are applied nationally and locally in districts/cities, confirming the systems, controls, and application in field (reality), both applied nationally, and regionally, confirming the obstacles in processing the permit. The information of the poultry slaughterhouse visited are shown in the Table 1.

\section{RESULTS AND DISCUSSIONS}

The building of poultry slaughterhouses in each kabupaten/kota area is regulated by each regional regulations in each area. These regulations are adjusted to the local
Table 1. The information of the slaughterhouse industry

\begin{tabular}{ll}
\hline The regions & \multicolumn{1}{c}{ The slaughterhouse company } \\
\hline Depok & $\begin{array}{l}\text { 1. PT. Amindo Prima Sejahtera } \\
\text { 2. Poultry Slaughterhouse owned by local } \\
\text { government in Tapos }\end{array}$ \\
Kabupaten Bekasi & $\begin{array}{l}\text { 1. Duta Makmur } \\
\text { 2. Pusaka Unggas }\end{array}$ \\
Kabupaten Bogor & $\begin{array}{l}\text { 1. PT. Karya Pangan Sejahtera } \\
\text { 2. PT. Ayam Jantan Perkasa }\end{array}$ \\
\hline
\end{tabular}

society and environtment. However, almost all areas have the same management order flow, as seen in the chart below (Figure 1).

\section{Depok}

The permits and procedures to build Poultry Slaughterhouse in Depok, as follows in Table 2. These procedures were obtained from interview with PT. Amindo Prima Sejahtera and also based on local regulation of Depok City Perda No.11/2013.

According to new local regulation of Depok City Perda No. 9/ 2015 about The Planning of Protection and Governance of Living Environment. It is said that both of slaughterhouses and poultry slaughter houses are only permitted to be built on Tapos sub-district area. Slaughterhouses and Poultry Slaughterhouses which has been built and has business license before the new Perda has been announced are still allowed to be built outside Tapos sub-district area. This makes many illegal slaughterhouses as it can not obtain an official business slaughterhouse permits, particularly the small slaughterhouse entrepreneurs who only have limited capital. They have not enough money for moving their slaughterhouse to Tapos sub-district area. In addition, the illegal slaughterhouse entrepreneurs do not want to propose the official permit that need long time and regulation.

Since 2011, the Depok government has not charged the tariff of levies on private animal slaughterhouse and poultry slaughterhouse. However, in accordance to Depok City Perda No. 7/2011, Depok Government charges the slaughtering service tariff for someone or companies who want slaughter their animal/poultry in animal slaughterhouse /poultry slaughterhouse that belong to the government. The amount of slaughtering service is 25,000 IDR per head for cattle/buffalo/horse and 100 IDR per head for poultry.

\section{Kabupaten Bogor}

The basis of the regulation of the building of slaughterhouse is Perda No.8/2003, about : Permit of Animal Husbandry and Fishery Busines in Bogor District Article 21 , about the requirements in getting permits on animal husbandry, cultivation, and Slaughterhouse as follows:

- Having Principle Permits of District Mayor

- Filling Permits Proposal Forms

- Attaching Copy of ID Card

- Attaching Copy of Certificate of Incorporation (for Company)

- Attaching Copy of Location Permit/Izin Peruntukan 


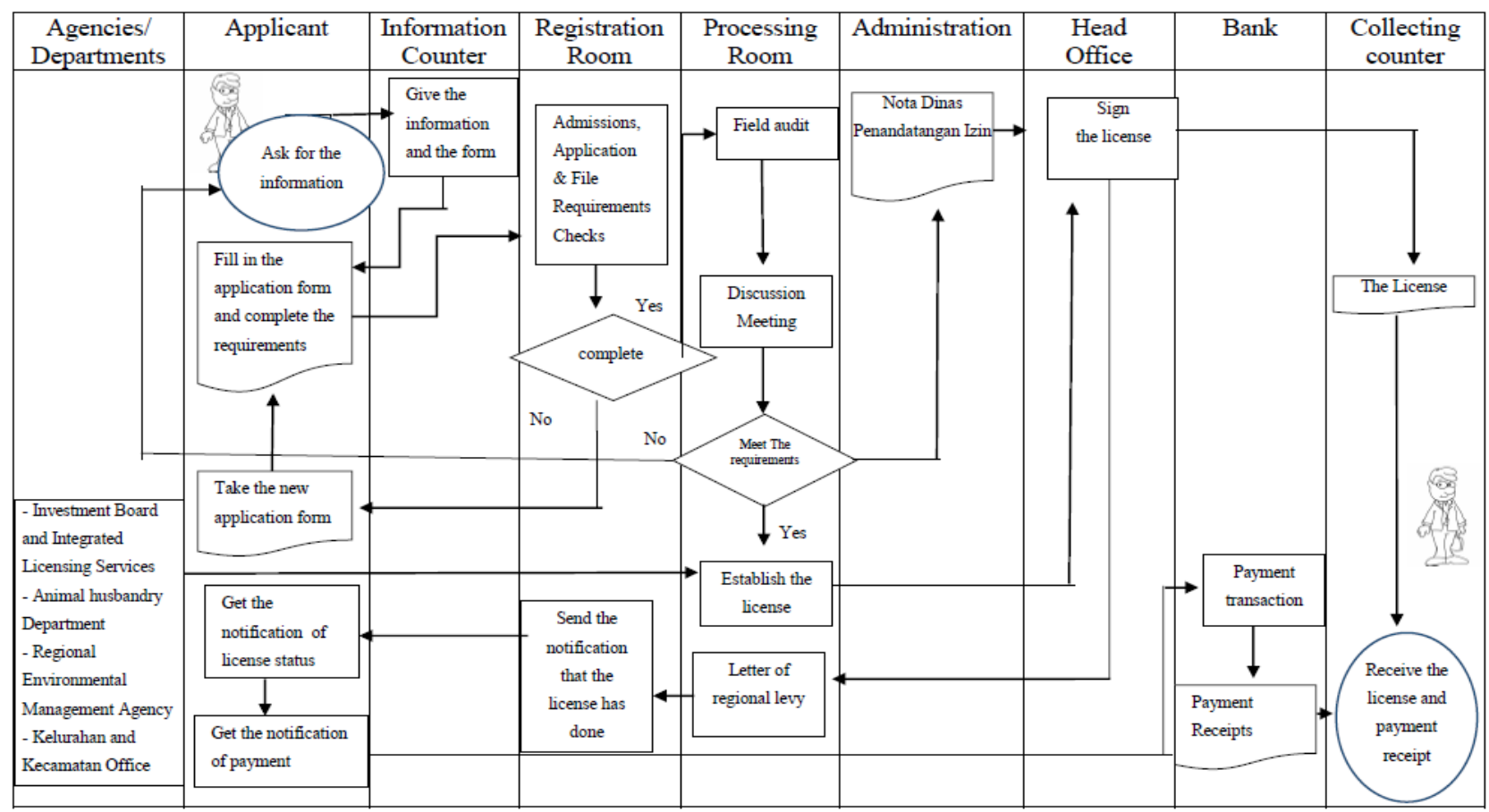

Figure 1. Flow Chart of Animal Slaughterhouse permits services

Table 2. The permits and procedures to build Poultry Slaughterhouse in Depok

Official Requirements and Regulation to build The details and procedures

Poultry Slaughterhouses

1. Space Uses Permit 1. The issuing authority: BPMP2T (Investment Board and Integrated Licensing Services) in "Dinas Depok" Office

2. Average time: 2 weeks

3. Official cost: 0 IDR (the service paid by the local government)

4. Procedural steps:

- Submit the documents to BPMP2T.

- Monitoring by Dinas Depok

- License issued

2. IMB (Building Permit)

1. The issuing authority: BPMP2T (Investment Board and Integrated Licensing Services) in "Dinas Depok" Office

2. Average time: 3 weeks

3. Official cost: 0 IDR (the service paid by the local government)

4. Procedural steps:

- Submit the documents to BPMP2T.

- Monitoring by Dinas Depok

- License issued

3. Application of Commercial Site Plans

1. The issuing authority: BPMP2T (Investment Board and Integrated Licensing Services) in "Dinas Depok" Office

2. Average time: 3 weeks

3. Official cost: 0 IDR (the service paid by the local government)

4. Procedural steps:

- Submit the documents to BPMP2T.

- Monitoring by Dinas Depok

- License issued

4. /HO (Hinder Ordonantie)

1. The issuing authority: BPMP2T (Investment Board and Integrated Licensing Services) in "Dinas Depok" Office 
Apriantini et al.

Jurnal Ilmu Produksi dan Teknologi Hasil Peternakan 5 (1): 15-22

Disturbance permission

2. Average time: 1 month

3. Official cost: 7.500.000 IDR

4. Procedural steps:

- Statement letter from local residents around poultry slaughterhouse

- Submit the documents to BPMP2T.

- Monitoring by Dinas Depok

- License issued

5. Company Business License 1. The issuing authority: BPMP2T (Investment Board and Integrated Licensing Services) in "Dinas Depok" Office

2. Average time: 1 month

3. Official cost: 0 IDR (the service paid by the local government)

4. Procedural steps:

- Submit the documents to BPMP2T.

- Monitoring by Dinas Depok

- License issued

6. Industrial Registered License 1. The issuing authority: BPMP2T (Investment Board and Integrated Licensing Services) in "Dinas Depok" Office

2. Average time: 2 weeks

3. Official cost: 0 IDR(the service paid by the local government)

4. Procedural steps:

- Submit the documents to BPMP2T.

- License issued

7. Certificate of Company Registration

1. The issuing authority: BPMP2T (Investment Board and Integrated Licensing Services) in "Dinas Depok" Office

2. Average time: 2 weeks

3. Official cost: 0 IDR (the service paid by the local government)

4. Procedural steps:

- Submit the documents to BPMP2T.

- License issued

8.Certificate of Business Domicile in Kelurahan 1. The issuing authority: Kelurahan Office

level

2. Average time: 1 week

3. Official cost: 0 IDR (the service paid by the local government)

4. Procedural steps:

- Submit the documents to Kelurahan office.

- Certificate issued

9. Certificate of Business Domicile (SKDU) in 1. The issuing authority: Kecamatan Office

Kecamatan level

2. Average time: 1 week

3. Official cost: 0 IDR (the service paid by the local government)

4. Procedural steps:

- Submit the documents to Kecamatan office.

- Certificate issued

\begin{tabular}{ll}
\hline 10. Certificate of Slaughter Officer & 1. The issuing authority: MUI Depok \\
& 2. Average time: 3 weeks \\
& 3. Procedural steps: \\
& - Submit the Application Letter to MUI Depok \\
& - Field Audit (Slaughter Officer and production process flow) by MUI Depok \\
& - Certificate issued \\
\hline
\end{tabular}

11. Halal Certificate

1. The issuing authority: MUI in Province Level (Bandung) 


\begin{tabular}{|c|c|}
\hline & 2. Average time: 2 months \\
\hline & 3. Official cost: 4.400 .000 IDR \\
\hline & 4. Procedural steps: \\
\hline & - Training team of Halal Assurance System (SJH) in MUI Province \\
\hline & - Fill in the SJH Manual Form \\
\hline & - Submit the manual form and documents \\
\hline & - Pay the service \\
\hline & - Field Audit by MUI Province \\
\hline & - Revision the manual form \\
\hline & - Halal Certificate issued \\
\hline \multirow[t]{7}{*}{ 12. Poultry slaughter Business License } & $\begin{array}{l}\text { 1. The issuing authority: BPMP2T (Investment Board and Integrated Licensing Ser- } \\
\text { vices) in "Dinas Depok" Office }\end{array}$ \\
\hline & 2. Average time: 3 weeks \\
\hline & 3. Official cost: 0 IDR (the service paid by the local government) \\
\hline & 4. Procedural steps: \\
\hline & - Submit the documents to BPMP2T. \\
\hline & - Audit and monitoring by dinas depok \\
\hline & - License issued \\
\hline \multirow[t]{2}{*}{ 13. Updating UKL-UPL } & $\begin{array}{l}\text { 1. The issuing authority: BPMP2T (Investment Board and Integrated Licensing Ser- } \\
\text { vices) in "Dinas Depok" Office }\end{array}$ \\
\hline & 2. Official cost: 0 IDR (the service paid by the local government) \\
\hline \multirow[t]{7}{*}{ 14. Permit letter for taking water } & 1. The issuing authority: Dinas in Province level \\
\hline & 2. Average time: 5 months \\
\hline & 3. Official cost: 0 IDR (the service paid by the local government) \\
\hline & 4. Procedural steps: \\
\hline & - Submit the application letter to Dinas in Province Level \\
\hline & - Audit and monitoring from dinas in Province level \\
\hline & - License issued \\
\hline \multirow[t]{8}{*}{ 15. Veterinary control number } & $\begin{array}{l}\text { 1. The issuing authority: "Dinas Peternakan" (Regency Department of Animal Hus- } \\
\text { bandry) in Province level }\end{array}$ \\
\hline & 2. Average time: 1 year \\
\hline & 3. Official cost: 0 IDR (the service paid by the local government) \\
\hline & 4. Procedural steps: \\
\hline & - Submit the documents to "Dinas Peternakan" in Province Level \\
\hline & - Audit and monitoring by dinas in Province level \\
\hline & -Revision the documents \\
\hline & - License issued \\
\hline
\end{tabular}

Penggunaan Tanah a.k.a. IPPT (Land Designation Usage Permit)

- Attaching Copy of Upaya Pengelolaan Lingkungan Hidup dan Upaya Pemantauan Lingkungan Hidup a.k.a. UKL/UPL (Efforts to Environmental Management/Efforts to Environmental Monitoring)

- Attaching Izin Mendirikan Bangunan a.k.a. IMB (Building Permit)

- Attaching Disorder Legislation Permit/Hinder Ordonnantie a.k.a. HO or Business Place License

- Attaching Nomor Pokok Wajib Pajak a.k.a. NPWP (Tax Payer Number)

\section{Application Process:}

- Application of advice planning to Dinas Pekerjaan
Umum dan Peruntukan Ruang a.k.a. DPUPR (Civil Work and Designation Space Regional Government) majority information of Animal Husbandry Spatial Designation/Slaughterhouse

- Application of Principle Approval to Dinas Penanaman Modal dan Perizinan Terpadu Satu Pintu a.k.a. DPMPTSP (Investment Board and Integrated Licensing Services Regional Government)

- Application of Izin Peruntukan Penggunaan Tanah a.k.a. IPPT to DPMPTSP

- Application of site plan to DPUPR

- Application of IMB to DPMPTSP

- Application of UKL/UPL to Badan Lingkungan Hidup a.k.a. BLH (Environmental Agency)

- Application of Disorder Legislation Permit/HO to 


\section{DPMPTSP}

- Application of Business Operational Permit to DPMPTSP

- Application of Halal Certificate to Provincial Majelis Ulama Indonesia (MUI) for 1 month processing duration. One of the requirements is having Juru Sembelih Halal a.k.a. JULEHA (certificated halal slaughterer) which the certificate is issued by District MUI for 1 week processing duration

- Application of Surat Nomor Kontrol Veteriner a.k.a. NKV (Veterinary Control Number). The process begins with applying to the office of animal husbandry district government, then the district government will visit and audit.Three days after the audit, letter of recommendation will be given then will be brought with other documents to the office of animal husbandry province government. Fourteen days after the proposal, province government will start the audit. Fourteen days after Poultry Slaughterhouse revise the requirements, a letter of NKV will be issued.

\section{The cost}

The cost is only charged to get a halal certificate. For registration of 220,000 IDR and for audit fee of 3 million IDR. In addition, the other cost is to get $\mathrm{HO}$ permit fee of $250 \mathrm{IDR} / \mathrm{m}^{2}$.

\section{The constraints of poultry slaughterhouse business establishment}

The problem to get poultry slaughterhouse permit both in Kota Bogor and Kabupaten Bogor is due to the regulations on urban spatial layout. Many poultry slaughterhouse are located in areas which are aimed not for agricultural land or are located in residential areas, thus it becomes their obstacle to legalize their business. Some of middle slaughterhouses failed to get aid from Netherlands because they did not have slaughterhouse license and they could not process the license due to their location.

However, Kabupaten Bogor revised the Regional Regulation No. 19 of 2008 on Spatial Planning of Bogor Regency 2005-2025 to become Regulation number 11 of 2016 on spatial planning of Bogor Regency Year 2016-2036. Regarding this local regulation, Poultry slaughterhouse can be built in Urban residential areas (dense residence) / code Pp1 as long as they have neighbour permission. Due to this new regulation, both small and medium poultry slaughterhouses are able to apply the permits.

\section{Bekasi}

The permits to build slaughterhouse in Bekasi based on Keputusan Bupati Bekasi No.503/Kep.53-BPPT/2010 as shown in Table 3. Stakeholders are required to pay the tariff of retribution to get the slaughter house License of 50 IDR per head of poultry. The picture (Figure 2) below illustrates the procedure flow to get slaughter house license in Bekasi and step point where the broker can help the company in processing the license (Perda Bupati Bekasi, 2010).

Both in kota and Kabupaten Bekasi do not have local regulation (Perda) about spatial plan for animal and poultry slaughterhouse. The constrains to have legal poultry slaughterhouse in Bekasi are (1) small slaughterhouses have not much capital to build big and permitted slaughterhouse, (2) land prices in Bekasi are too expensive, (3) poultry slaughter business still in small capacity and self-owned, (4) it is needed 20 Million Rupiahs to pay the third party (broker) to build a slaughter-house. The third party (broker) will help to make an environment "analysis" and take care for all permits making process until done (Figure 2), (5) Some permits are served in Investment Board and Integrated Licensing Services (BPMPPT), but they are still need technical recommendation letter from different related

Table 3. The permits to build Poultry Slaughterhouse in Bekasi

\begin{tabular}{|c|c|}
\hline Permits & The issuing authority: \\
\hline 1. Location Principle Permits & 1. Bappeda Kab. Bekasi \\
\hline 2. Land Technical Considerations & 2. Land Office Bekasi \\
\hline 3. Location permit for poultry slaughtering purposes & 3. BPMPPT (Investment Board and Integrated Licensing Services) \\
\hline 4. Land use aspect & 4. Distarkim (Department of spatial planning) \\
\hline 5. Plot map & 5. Distarkim (Department of spatial planning) \\
\hline 6. Site Plan & 6. Building Departement \\
\hline 7. Disturbing Permit (HO) & 7. BPMPPT (Investment Board and Integrated Licensing Services) \\
\hline 8. Land Allotment Permit & 8. BPMPPT (Investment Board and Integrated Licensing Services) \\
\hline 9. Recommendation of business permit for Poultry Slaughterhouse & 9. DPPK (Local Departement of animal husbandry) \\
\hline 10.Recommendation of poultry slaughterhouse & 10. Kecamatan Office \\
\hline 11. Liquid waste disposal permits & 11. Agency for Environmental Control. \\
\hline 12. License for taking underground water & 12. Agency for Environmental Control \\
\hline 13. License of landfills & 13. Agency for Environmental Control \\
\hline 14. Building permit & $\begin{array}{l}\text { 14. BPMPPT (Investment Board and Integrated Licensing Ser- } \\
\text { vices) }\end{array}$ \\
\hline 15. Certificate of Business Domicile & 15. Kelurahan Office \\
\hline 16. Small Trading Business License & $\begin{array}{l}\text { 16. BPMPPT (Investment Board and Integrated Licensing Ser- } \\
\text { vices) }\end{array}$ \\
\hline
\end{tabular}




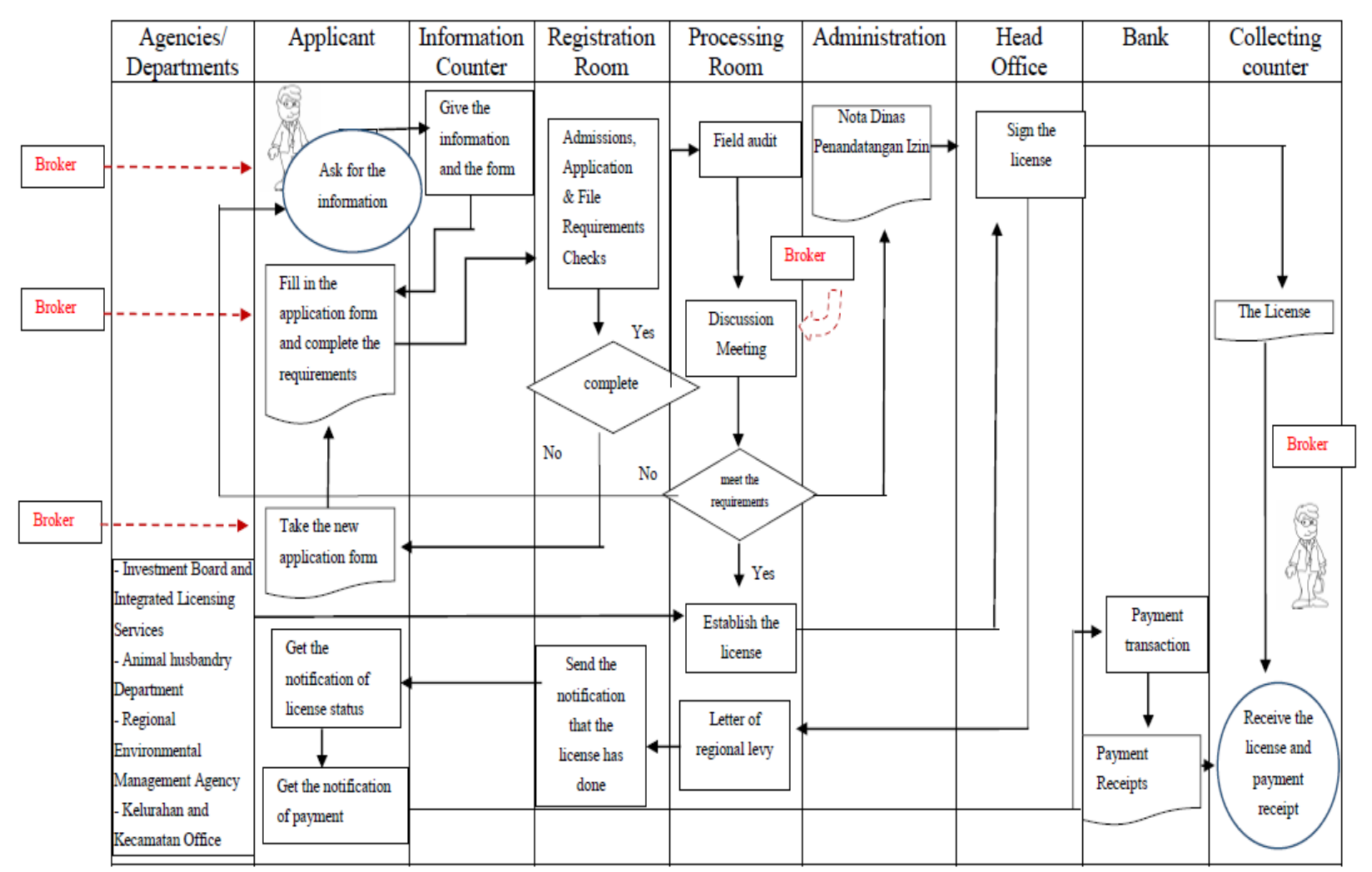

Figure 2. Flow Chart of Animal Slaughterhouse permits services in Kabupaten Bekasi

department (dinas). Therefore the stakeholders have to come to the related department (dinas) each by each. With the help of the third party (broker), the third party will take care all of the recommendation letter issuing process until the permits are issued (done), (6) nowdays, slaughterhouse building process still has not been the priority policy from the central government nor Bekasi government, (7) limitations of human resources in the office of Bekasi animal husbandry regional government (dinas) to manage and control the slaughterhouses in the area of Bekasi which has a large area. (8) Frequent rotation of employees in the office of animal husbandry. Sometimes the new employees do not know the problems occurred in the field.

\section{Tangerang}

There is no any Local Government Rule that controls the set up of the building of poultry slaughterhouses both in Kabupaten Tangerang and South Tangerang. The building of poultry slaughterhouses only refer to Permentan No.13 of 2010 such as, Building Permit (IMB) and Veterinary Control Number (NKV). There are no legal small and medium-sized poultry slaughterhouses in Tangerang. The stakeholders do not want to have legal slaughterhouse because:

- Stakeholders (small poultry slaughterhouses) have not enough money to fulfill the requirements in building the permitted slaughterhouse.

- Stakeholders do not want to be tied with the government or any parties' rules and systems.

- Stakeholders do not want pay too much attention in processing the permits.

- Stakeholders only focus on how the business could run and the capital flows regularly, without caring about the hygiene of poultry slaughter location.

Because of these reasons, only poultry slaughterhouses with large capital and multinational scale which have legal permission.

\section{CONCLUSIONS}

Generally, there is no obstacle in any permit to build the poultry slaughterhouse. The procedures are relatively easy as long as all documents required are complete and the company focuses on completing or revising the required documents immediately. However, the problem usually occurs because of the location permit in build poultry slaughterhouse and because each region has different regional regulations on urban planning.

The other problem that may be occured is the capital limitations of the stakeholders, thus they do not have enough money to build standard slaughterhouses and they do not want to be tied with the government or any parties' rules and systems.

In addition, most of the permits are issued by Investment Board and Integrated Licensing Services (BPMPPT). However, when the stakeholders apply the permits in BPMPPT, they should also attach letters of technical recommendation from different departments/ agencies (dinas). Thus, they have to visit to the related departement each by each to get a letter of technical recommendation. This bureaucratic problem extends the processing time. 


\section{Recommendation}

Government should be more focused on improving small and medium scale poultry slaughterhouse. Permits and technical recommendation issuing process should be done in one place, that is Investment Board and Integrated Licensing Services (BPMPPT) to shorten the processing time. Moreover, government or international aid should be able to provide venture capital assistance for small poultry slaughterhouses, therefore they can move to the recommended area and build the standard poultry slaughterhouses.

\section{AKNOWLEDGEMENT}

Research presented in this publication was financially supported by Wageningen Bioveterinary Research, Netherland, in order to develop and improve small and medium scale poultry slaughterhouse in Indonesia.

\section{REFERENCES}

Keputusan Bupati Bekasi No. 503/Kep.53-BPPT/2010. 2010. Tentang prosedur Tetap/ Standard Operating Procedure (SOP) Penyelenggaraan Pelayanan Perizinan Pada Badan Pelayanan Perizinan Terpadu Kabupaten Bekasi.

Peraturan Menteri Pertanian No. 13/OT.140/1/2010. 2010. Tentang Persyaratan Rumah Potong Hewan Ruminansia dan Unit Penanganan Daging (Meat Cutting Plant).

Peraturan Pemerintah Republik Indonesia No.95/2012. 2012. Tentang Kesehatan Masyarakat Veteriner dan Kesejahteraan Hewan.

Perda Kota Depok No.9/2015. 2015. Tentang Rencana Perlindungan dan Pengelolaan Lingkungan Hidup.

Perda Kota Depok No.11/2013. 2013. Tentang Perubahan Atas Peraturan Daerah Kota Depok Nomor 22 Tahun 2003 Tentang Izin Usaha Perikanan, Peternakan dan Pemotongan Hewan.

Perda Kota Depok No. 17/2011. 2011. Tentang Izin Gangguan dan Retribusi Izin Gangguan.
Perda Kota Depok No.7/2011. 2011. Tentang Retribusi Rumah Potong Hewan.

Perbup nomor 36/2015. 2015. Tentang Pendelegasian Kewenangan Penandatanganan Dokumen Administrasi Pelayanan Perizinan dan Non Perizinan kepada Kepala Satuan Daerah.

Perda Kabupaten Bogor No. 8/2003. 2003. Tentang Izin Usaha Peternakan dan Perikanan Kabupaten Bogor.

Perda Kabupaten Bogor No.29/2011. 2011. Tentang Retribusi Jasa Usaha.

Perda Kabupaten Bogor No. 19/2008. 2008. Tentang Rencana Tata Ruang Wilayah Kabupaten Bogor Tahun 2005-2025.

Perda Kabupaten Bogor No.11/2016. 2016. Tentang Rencana Tata Ruang Wilayah Kabupaten Bogor Tahun 2016-2036.

Rochadi T, Rachmawan, and R DA. 2013. Physical and Technical Feasibility Procedure slaughter at Government Abbatoir in West Java.p 2-3; 5 th National Seminar on Sustainable Livestock Development; Animal Husbandry Faculty UniversitasPadjadjaran,N opember12,2013:availableat, https://www.academia. edu/5096644/Physical_and_Technical_Feasibility_ Procedure_slaughter_at_the_Government_Abattoir_ in_West_Java

Rochadi T, and Rivanda DA. 2014. The Model Of Competitive Slaughterhouse Management in West Java, Indonesia. The Journal "Scientific Papers, Animal Science Series" published by the Faculty of Animal Science, belonging of the "ION IONESCU DE LA BRAD” University of Agricultural Sciences and Veterinary Medicine, Iasi. 62 : 106-109.

Undang-Undang Republik Indonesia No.41/2014. 2014. Tentang Perubahan Atas Undang-Undang Nomor 18 tahun 2009 Tentang Peternakan dan Kesehatan Hewan. 